\title{
Historical narratives as strategic resources: an analysis of the Turkish international contracting sector
}

Article

Accepted Version

Duman, D. U., Green, S. D. and Larsen, G. D. (2019)

Historical narratives as strategic resources: an analysis of the Turkish international contracting sector. Construction Management and Economics, 37 (7). pp. 367-383. ISSN 01446193 doi: https://doi.org/10.1080/01446193.2018.1529416 Available at https://centaur.reading.ac.uk/79629/

It is advisable to refer to the publisher's version if you intend to cite from the work. See Guidance on citing.

To link to this article DOI: http://dx.doi.org/10.1080/01446193.2018.1529416

Publisher: Taylor \& Francis

All outputs in CentAUR are protected by Intellectual Property Rights law, including copyright law. Copyright and IPR is retained by the creators or other copyright holders. Terms and conditions for use of this material are defined in the End User Agreement.

www.reading.ac.uk/centaur 
Central Archive at the University of Reading

Reading's research outputs online 


\section{HISTORICAL NARRATIVES AS STRATEGIC RESOURCES: AN ANALYSIS OF THE TURKISH INTERNATIONAL CONTRACTING SECTOR}

The Turkish contracting sector has an enviable reputation for operating in highrisk international markets. The sector's ability to respond to market instability could meaningfully be construed as sectoral-level capability. We aim to demonstrate how history can be mobilised in a formalised 'strategy text' to create a strategic narrative on the sectoral level. The Geography of Contractors as published by the Turkish Contractors Association (TCA) ostensively portrays the strategic development of Turkish international contractors over four decades. Such quasi-historical narratives are routinely mobilised for the purposes of creating a shared memory on the sectoral level. The chosen strategy text draws from multiple narrative fragments derived from past experience to generate a strategic agenda for the future. The representation given to multiple voices reflects the pluralistic nature of strategy making praxis. The overarching strategy narrative reflects a performative intent in legitimising some practices whilst discrediting others. Narrative analysis demonstrates the way in which actors, actions and events are positioned within a plot structure, with direct implications for the enactment of future strategic practices. The findings suggest that strategic actions can only ever be identified in retrospect, and that such arguments are always made with an eye on the future.

Keywords: Competitive strategy, narrative turn, international contracting, Turkish contractors, narrative analysis

\section{Introduction}

Competitive strategy in the construction sector has been explored from a range of different theoretical perspectives. Much of the literature is characterized by implicit assumptions of economic and political stability, or at least by an expectation that trajectories of change are 
predictable (cf. Dikmen and Birgönül, 2003, Korkmaz and Messner, 2008, Lee et al., 2011). Such assumptions have limited validity in the context of the highly unstable markets within which international contractors currently operate. More recent research has moved the debate away from rationalistic explanations towards a focus on the dynamic interactions between contracting firms and the contextual landscape within which they operate (e.g. Fernie et al., 2006; Kao et al., 2009). Such studies have opened up the space for more constructionist perspectives, including those which conceptualise competitive strategy as a discourse (cf. Green et al., 2008a). However, as yet little attention has been given to understanding the competitive strategy of international contractors from a narrative perspective. The purpose of this paper is to accentuate the socially constructed and discursive nature of competitive strategy by drawing from the 'narrative turn' (e.g. Brown and Thompson, 2013; Czarniawska, 2004; Vaara et al., 2016). The aim is to explore the extent to which the formulation of strategy can meaningfully be understood through a narrative analysis of a formalised 'strategy text'. The specific focus lies with the analysis of a quasi-historical narrative of the Turkish international contracting sector.

The central argument of the narrative turn is that individuals make sense of the world by telling stories, and that those stories inevitably frame the way we see the past and future (Fenton and Langley, 2011; Vaara et al., 2016). Of particular interest is the suggestion that narratives and stories are seen to be constitutive of organisational activity rather than simply representative (Czarniawska, 2004). Phrased rather differently, narratives work as a means of retrospective sense-making (Brown and Thompson, 2013). From a narrative perspective, it is axiomatic that we cannot access the past in an objective sense. Nevertheless, we can analyse the available narratives of what happened and draw appropriate conclusions. The focus on quasi-historical narratives is seen to be an original contribution to the current understanding 
of competitive strategy in the context of international contracting. It is further seen to have significant implications for future research, not least in terms of pointing towards quasihistorical narratives as important sources of empirical data.

The paper is structured as follows. First, the selected empirical focus on Turkish contractors operating in international market is introduced and justified. This is followed by the justification of the adopted approach derived from a critique of previous approaches to researching competitive strategy in construction. A particular emphasis is placed on the use of historical narratives as strategic resources (cf. Foster et al., 2017). The details of the empirical study are then introduced together with the adopted narrative methods. Thereafter, the findings of the empirical analysis are described and discussed. Finally, conclusions are offered in respect of the broader implications of the research beyond the selected empirical context of Turkish international contracting.

\section{TURKISH CONTRACTORS IN THE GEO-POLITICAL CONTEXT}

Turkish contractors are commonly held to have first commenced international operations in 1972 (TCA, 2017). As such they significantly lagged behind their competitors from Europe and the United States who have been active in international markets since the early 1900 s (Mawhinney, 2001; Langford and Male, 2001). Yet, despite being late starters, by 2016 Turkish contractors accounted for 46 of the top 250 contractors in the international ranking produced by Engineering News Record (ENR, 2017). Whilst such rankings are undoubtedly subject to manipulation, those produced by ENR stand up well to academic scrutiny (Lu, 2014). The initial interest of Turkish contractors in international markets can be traced back to the domestic economic recession of the early 1970s (Giritli et al., 1990). Turkish contractors were hence in part forced to look at international markets, but at the same time the oil boom of the 1970s created a massive demand for construction across the Middle East 
and North Africa (MENA) region. Construction companies from the US, Europe and Japan dominated the international market during this period, with the progressive involvement of firms from emerging economies such as Turkey and Korea as sub-contractors (Raftery et al., 1998). However, political and economic instabilities throughout MENA in the 1980s led Western contractors to withdraw from these markets in favour of the relatively stable markets of the West (Crosthwaite, 2000). Turkish contractors however followed a different trajectory by relishing opportunities in markets which were deemed by Western firms to be unattractive. They were successful in dramatically increasing their presence in MENA countries throughout the 1980s. In 1978 Turkish firms collectively accounted for US \$1629 million of international contracts; by June 1987 this had increased to US \$17 billion (Giritli et al., 1990). No less than $91 \%$ of this work had been secured in Libya and Saudi Arabia (op. cit.). International activity of Turkish contractors reached a new plateau during the 1990s as a result of their successful involvement in the Commonwealth of Independent States (CIS) following the dissolution of the Soviet Union (USSR) in 1991. The Russian Federation and other post-Soviet countries notably accounted for $60 \%$ of the international business of Turkish contractors in the period 1990-1999 (TCA, 2017).

The advent of the new millennium saw continued market penetration by Turkish contractors, especially within the newly independent republics of Central Asia along the southern fringe of the former USSR. This period was characterised by specialisation in specific sectors with corresponding increases in turnover through to 2007 (TCA, 2017). Figure 1 summarizes the annual project values of Turkish International contractors from 2002 through to 2016. The sharp drop in output in 2009 can be attributed in part to the global financial recession. MENA markets were further subsequently suppressed as a consequence of political instability in the wake of the so-called Arab Spring of 2010. Turkish contractors were subsequently challenged 
by deteriorating diplomatic relations between Turkey and Russia following the shooting down of a Russian warplane by the Turkish air force over Syria in 2015. Turkish contractors have notably been successful in navigating a prolonged period of instability across the Middle East, comprising not only the ongoing civil war in Syria but a series of conflicts in Afghanistan and Iraq. Libya was an especially important market prior to the 2011 overthrow of Colonel Gaddafi which rendered market growth predictions redundant almost overnight. Given the geo-politically fractured contexts in which Turkish contractors operate, the extent to which the current construction-related literature on competitive strategy offers meaningful insights is at best contestable. Further uncertainty has most recently been created by a diplomatic row between Turkey and the USA resulting in a currency crisis and ongoing threats of a pending trade war.

\section{INSERT FIGURE 1}

\section{UNDERSTANDING COMPETITIVE STRATEGY}

\section{Competitive positioning and the enduring logic of SWOT analysis}

The notion of 'competitive strategy' has been of central importance to scholars of organisation studies ever since the professionalisation of management as a discipline in the aftermath of World War II. The very phrase is indicative of a commitment to market competition whereby each firm strives to outdo its competitors. Early models of strategy tended to reflect the faith in top-down rational planning which prevailed at the time (e.g. Ansoff, 1965; Chandler, 1972). Porter's (1980) 'competitive positioning' approach was especially influential in advocating the analysis of markets in terms of their supposed objective characteristics. On the basis of such analysis, firms are supposedly able to position 
themselves to best advantage. Porter's approach has long-since been popular amongst scholars interested in the construction sector, not least those interested in the competitive strategy of Turkish contractors (e.g. Öz, 2001; Dikmen and Birgönül, 2003; Özorhon, 2012).

It is notable that the three sources cited above are primarily interested in understanding 'sources of competitive advantage'. What they are rather less interested in are the processes through which competitive strategy is enacted, and how such processes evolve over time. Öz (2001) comprises a desktop study using Porter's (1990) diamond framework as the primary framework for analysis. Özorhon (2012) likewise adopts Porter's diamond framework which she populates with empirical data from 65 interviews conducted across 27 firms. Additional insights are gained from a SWOT analysis. While such sources undoubtedly make useful contributions to so-called 'formistic knowledge' they say almost nothing about the way in which strategy is performed in practice (cf. Tsoukas, 1994). In essence, they are primarily focused on describing the determinants of success, with an implicit assumption that these will continue to prevail in the future. This emphasis is of course by no means unique to the literature on Turkish contracting; it is equally apparent more broadly amongst researchers interested in competitive advantage in construction (e.g. Ofori, 2003; Flanagan et al., 2007; Zhao et al., 2009).

Dikmen and Birgönül (2003) draw more liberally from Porter's (1980) three generic strategies of cost leadership, differentiation and focus. Their particular interest lies in the three-way interaction between objectives, strategies and competencies. They collected data from 60 members of the TCA by means of a questionnaire survey, appropriately supplemented by face-to-face interviews. The responses were subjected to statistical analysis and conclusions were drawn vis-à-vis issues such as strategic decision-making, company competences and market strategies. 
The overriding tendency of approaches such as those described above is to classify the determinants of competitive advantage into factors, which are then in some way 'validated'. The underlying perspective is heavily shaped by Porter's concept of competitive positioning, while at the same time recognising the importance of key capabilities. As such, the above cited sources refer to both the exogenous characteristics of targeted markets and the endogenous capabilities of the sector. Techniques such as SWOT analysis are habitually advocated for the purposes of making strategic recommendations.

The 'opportunities and threats' components of the SWOT analyses tend to refer to the supposed exogenous characteristics of identified markets with associated assumptions of stability. The environment within which firms operate is notably construed as a potentially fully describable entity (cf. Tsoukas, 1994). The components of the SWOT analyses labelled 'strengths and weaknesses' are in turn usually related to the capabilities which a given sector possesses (or notably lacks). These are likewise assumed to be directly accessible and hence subject to codification leading to statistical analysis of the adjudged relative importance (cf. Dikmen and Birgönül, 2003). Sources such as Zhao et al. (2009) allude to the disadvantages of not being familiar with the 'local system' in terms of regulations and procurement approaches. There is also a broad consensus regarding the importance of maintaining good client relationships and the pivotal role of government. Öz (2001) notably criticises the Turkish government for failing to assume a sufficiently active role in supporting Turkish contractors to enter new markets. In contrast, Zhao et al. (2009) highlight the key role of the Chinese Government in improving the competitiveness of Chinese international contractors (CICs). The continued reification on 'competitiveness' hence never quite seems to escape the geo-political realities of mercantilism. 


\section{Resources, competences and capabilities}

Returning to the theoretical underpinnings of the construction-related literature, it is clear that the overriding allegiance to Porter's competitive-positioning school is routinely nuanced by notions of capability-building theory. The latter perspective emphasises the importance of endogenous factors such as resources, competences and capabilities. The broad approach is exemplified by Barney's (1991) resource-based view (RBV), which focuses on the strategic importance of unique resources which cannot easily be replicated by others. Prahalad and Hamel (1990) offer similar arguments in respect of core competences, and Grant (1996) extends the debate further with his knowledge-based view of the firm. Such approaches echo the logic of evolutionary economics in emphasising the importance of path dependency in shaping strategic choice (cf. Nelson and Winter, 1982). Hence competitive positioning is forever shaped and constrained by a firm's operating routines (or tacit knowledge) as developed over time.

An increasing awareness on the inherent unpredictability of (global) markets subsequently led to an emphasis on 'dynamic capabilities'. According to Teece et al. (1997) those firms that are able to reconfigure their operating routines in response to external change are the ones which are likely to be the most successful. Given the rapidly changing and discontinuous nature of the markets within which Turkish contractors operate the notion of dynamic capabilities has an obvious intuitive appeal. Zollo and Winter (2002) have been influential in arguing that that a dynamic capability is best understood as a 'learned and stable pattern of collective activity'. In this sense, dynamic capabilities are conceived as something that a firm does rather than something which it has (Green et al., 2008b). Any extension of these ideas to the sectoral level of Turkish international contracting would clearly be dependent upon the extent to which the 'learned and stable pattern of collective activity' 
could meaningfully be extended across organisational boundaries.

\section{Strategy-as-practice}

It would of course be misrepresentative to suggest that the above described evolution of theoretical ideas has been uncontested. Mintzberg $(1987,1990)$ has long since been critical of the very idea that strategy can be broken down into the two supposedly separate activities of 'planning' and 'doing'. He was especially critical of the idea that strategy is some sort of controlled process involving only senior managers and CEOs. Mintzberg (1990) also argues that planning and doing are irrevocably intertwined such that strategy more often than not emerges through a process of trial and error. He was further critical of any approach that sought to abstract generic principles outwith the context in which they are enacted. Strategy is hence best understood as an emergent stream of decisions which unfold over time.

The subsequently developed strategy-as-practice approach extends these arguments by emphasising the importance of the micro-level social activities, processes and practices that characterise the day-to-day realities of strategising (Whittington, 1996). Strategy is seen to be a 'flow of activity' which is enacted through the actions and interactions of multiple actors over time (Jarzabkowski, 2005). Whittington (2006) observes that researchers focus on strategy activity either at the level of individual organisation, or alternatively, on the aggregate effects of such activity at an inter-organisational level. In the latter case he likens strategy to an industry 'whose members from business, consultancy and beyond collectively produce the strategies and practices that help shape our world' (pg. 613). This perspective resonates with the proposed focus on Turkish international contracting whereby multiple actors collectively seek to shape emergent futures.

In seeking to bridge across the two levels of analysis, Whittington (2006) proposes the three 
dimensions of 'praxis, practices and practitioners'. 'Praxis' refers to the flow of activity in which strategy is accomplished, including board meetings, team briefings and even informal interactions around the photocopier. 'Practices' on the level of the organisation refer to the shared routines of behaviour, operating routines and the 'knowledge artefacts' produced by strategizing activity (such as the $2 \times 2$ matrices of SWOT analysis). On a sectoral level, practices might include horizon-scanning activities commissioned by organisations such as the TCA. Practices could also feasibly include externally generated strategy discourses such as competitive-positioning theory. Finally, 'practitioners' is used to describe the actors involved in making, shaping and executing strategy. Whittington (op. cit.) further emphasises the interconnectedness between the three concepts, and the dangers of addressing different levels in isolation.

The difficulty of course with the approach described above is how to know which particular practices are significant at any point in time, and the extent to they can be meaningfully disentangled from the flow of praxis (Jarzabkowski and Spee, 2009). To understand strategyas-practice on the level of the Turkish international contracting sector would hence risk becoming an insurmountable empirical challenge, especially if appropriate attention is given to different levels of analysis.

\section{Towards the narrative turn}

In light of the above expressed difficulties, attention is increasingly turning to the 'linguistic turn' which emphasises discursive and narrative approaches to the understanding of strategy (e.g. Barry and Elmes, 1997; Brown and Thompson, 2013). Such studies accentuate the importance of talk, text and conversation as the means of 'doing' strategy. Rather than trying to capture strategy-as-practice by direct observation, the narrative turn focuses on 'narratives of strategy' as the object of empirical analysis. On this basis Fenton and Langley (2011) add 
the idea of a 'strategy text' to three original dimensions of strategy-as-practice as proposed by Whittington (2006). Hence the agenda moves towards analysing narratives for the purposes of understanding how practitioners make sense of themselves, their practices and experiences in regard to strategy. Such a perspective focuses on the way strategies are depicted, appropriated, and championed through stories (e.g. Barry and Elmes, 1997). Löwstedt and Räisänen (2012) notably applied narrative analysis to 20 years of change processes in a Swedish construction company. They sought to compare the 'formal narratives' as stated in company documents with the individual spoken 'lived narratives' of middle managers. The findings illustrate how change events in the past are interpreted very differently by formal and lived narratives.

The key argument of the 'narrative turn' is that humans mobilize narratives to give meaning to past events, but also to provide an overall sense of direction for the future (Czarniawska, 2004). Such a perspective sees organisations as discursive spaces within which the narratives of different actors and interest groups continuously compete as sense-making mechanisms (Fenton and Langley, 2011). Through the narratives told in an organisation 'the present, past and future are all continuously retold, and rewritten, revealing organisations as fragile, transient and mutable accomplishments' (Brown and Thompson 2013:1149). It follows that the meanings embedded in narratives can provide insights into the discursive and socially constructed nature of competitive strategy. To be persuasive, such narratives should form temporal plot structures which connect the actors and events of the past in a shared, acceptable and plausible framework (De La Ville and Mounoud, 2015). When the intended audiences accept such narratives, they become available to others as 'strategic resources' for the purposes of generating future narratives and actions. In contrast to the majority of 
previous strategy research relating to construction, the narrative approach better reflects the inherent richness of strategy making (cf. Tsoukas, 1994).

By definition, 'strategy narratives' are constructed with a degree of performative intent. They are invariably produced by drawing from the past and labelling selective actions as 'strategic' (Foster et al., 2017). Hence actions are only ever labelled as strategic in retrospect, and always with a view to persuading an audience vis-à-vis a preferred course of action. The same logic would also apply to other constituent ingredients of the narrative, including actors, events and decisions. For the purposes of the current paper, the TCA publication Geography of Contractors (Tayanç, 2011) is interpreted as a 'strategic text' on the sectoral level. It draws from individual narrative fragments by senior managers from within the TCA membership. More pertinently, it connects them with an overriding plot structure which forms an historical narrative which tells the story ${ }^{1}$ of the development of Turkish international contracting.

\section{'Historical narratives' as a strategic resource}

The strategic use of historical narratives has in recent years attracted increasing interest not only within the field of business history (Foster et al., 2017), but also within organisation studies more generally (Adorisio, 2014). The advocates of path dependency have consistently invoked the importance of 'history' in terms of shaping and constraining strategic choice (e.g. Barney, 1991; Teece et al., 1997). Pettigrew (1997) also emphasises the importance of history in his heavily-contextualised longitudinal studies of strategy development. However,

\footnotetext{
${ }^{1}$ More precisely, the historical narrative presented in the Geography of Contracting tells $a$ story of international Turkish contracting. It is not intended to imply that this is the only story which could be told.
} 
Pettigrew's so-called 'Process School' is notable for emphasising an objective past which once fixed is thereafter assumed to remain unchangeable (Brunninge, 2009). Such realist approaches to history tend to reduce the past to a set of exogenous variables which are forever beyond the control of managers (Suddaby et al., 2010). In contrast, constructivist interpretations of the past can be seen as malleable assets which can be mobilised to serve different strategic purposes (Rowlinson et al., 2014). Key facts of course can remain fixed, but are nevertheless invariably subject to different interpretations to serve different purposes. Hence the argument that the historical narrative contained within the Geography of Contracting was deliberately created to serve a particular strategic purpose. As such, it constitutes a source of empirical data in terms of how the narrative was constructed, thereby providing insights into the way strategy on the sectoral level is constituted.

\section{RESEARCH METHOD}

The first half of this paper has built an argument for conceptualising strategy as a process of narrative construction. It has been argued that narratives of the past are constructed in accordance with a degree of performative intent vis-à-vis the future. The described research follows an established theme in adopting an interpretive narrative perspective (cf. Vaara et al., 2016). As advocated by Tsoukas (1994:772), conducting research by employing narratives as the object of the analysis enables the researcher to 'capture the many context dependent nuances, details, and flexible temporal connections that characterize strategy making'. Since the narrative perspective conceptualises social reality as a process of continuous construction, the search for objective truth is discounted and replaced instead with a quest to understand how a given version of the world is constructed (Czarniawska, 2004).

\section{Empirical data set: The epic story of Turkish contractors}

The empirical analysis focuses on the analysis of a formalized sectoral narrative published by 
the Turkish Contractors Association (TCA) as a quasi-historical book, Geography of Contractors (Tayanç, 2011). The source in question is an epic story of the Turkish international contracting sector's development with the explicit stated purpose of creating a common memory for the sector and providing a point of reference for subsequent generations.

The analysis described below provides a retrospective and contextualised understanding of strategy-as-practice on a sectoral level through the deconstruction of a formal narrative. It is based on the premise that strategy narratives constitute the temporal realities of strategy making (Fenton and Langley, 2011). Narrative analysis depicts the elaboration of an acceptable narrative, which casts the actors, actions and events of the past into an epic plot structure with an intended purpose (cf. Czarniawska, 2004).

The Geography of Contractors was published in Turkish and at the time of writing remains publicly available on the TCA website. The TCA is the primary membership organisation representing the interests of large Turkish-owned construction companies operating in international markets. It publishes regular periodic sectoral reports on international contracting and hence continuously projects a series of authoritative narratives in support of Turkish contracting. The book was developed by the TCA as a special project in partnership with the History Foundation of Turkey. The latter is a publishing institution specialising in sectoral and organisational level narratives. The ostensive aim of the book is to provide an explanation of how Turkish contracting firms have remained competitive in international markets over the course of several decades. The preface by the then president of TCA notably sets the tone in suitably epic terms:

In this book you will find the story of Turkish contractors spreading to 83 countries of the world by the end of 2010.... You will meet the exciting proud adventure describing how they have stretched from Libyan deserts to Russian steppes, from Central Asia, 
Europe, the America continents to the interior of Africa, and how they have managed to fit such a story into 38 years. (Erdal Eren cited in Tayanç 2011:13)

The preface notably also includes contributions from the president and prime minister of Turkey at the time of publication. Such narrative fragments not only emphasize the heroic success of Turkish international contracting sector for the broader Turkish economy, but also highlight the longstanding nature of the success story. The narrative depicts individual firms, projects and markets chronologically in a supposedly realist timeline. However, it also contains 54 'narrative fragments' derived from politicians, industry representatives and senior managers from within contracting firms. Insights can be gleaned not only from the narrative fragments themselves, but also from the very fact that they were chosen for inclusion. It is contended that the TCA narrative draws from the past selectively to provide a framework for the selected stories, otherwise interpreted as an epic plot structure. The book includes a summary analysis of the sector's development based on Porter's diamond framework, but this is strikingly entirely marginal to the way in which the subsequent narrative unfolds. The narrative as a whole is notable for the way in which it assigns heroic roles to key individuals in forging the success of Turkish contractors. The epic plot structure can further be seen to position other individuals as villains, whilst also referring to obstacles which had to be overcome (cf. Barry and Elmes, 1997). The narrative of course is strengthened if it is supported by facts, but it is not the facts themselves which tell the story. In short, the TCA's publication can be seen to provide a sectoral level strategic narrative aimed at reinforcing the competitiveness of Turkish international contractors. It hence comprises a primary empirical source which lends itself to analysis as a 'strategy text'.

\section{Narrative analysis method}


It has been argued that historical narratives organize a flux of events, actors, actions and contextual parameters into a whole to provide an explanation for an intended purpose (cf. Polkinghorne, 1998). Linking such narrative elements along a temporal dimension and identifying supposed causalities can further be conceptualised as an intrinsic part of the process of narrative construction (Fenton and Langley, 2011). According to Greimas (1987), all narratives focus on a subject (or 'hero') who follows a journey to reach an object (or 'endgoal'). Each narrative journey routinely describes how the subject interacts with a series of characters at different stages of the process to reach the stated end-goal. The characters described may be human, or on occasion, agency may be ascribed to inanimate events or even to abstract concepts. The same characters may be presented as heroes or villains at different times. Many narratives build particular plot lines around the tendencies of heroes to subsequently turn into villains, and vice versa (Czarniawska, 2004). By interpreting such temporal and dynamic connections across an extended timeline, narrative analysis provides a means of understanding the essential temporality associated with the negotiation and enactment of strategy. Barry and Elmes $(1997 ; 432)$ identify two complementary methods of narrative analysis by arguing that 'narrativity encompasses both the telling and the told'. The first focuses on the structural elements of narrative in terms of how the story is constructed. Such an approach tends to focus on the plot structure, identifying the interactions between the various actors, actions and events within a depicted contextual setting (Holstein and Gubrium, 2011).

The second identified method comprises thematic analysis and focuses on the role of the narrative in creating a shared social reality for the benefit of the intended audience. Thematic analysis focuses solely on issues of content and provides a means of understanding 'what is told' (Riessman, 2008). The adopted approach drew from both structural and thematic analysis, often iterating between the two. 
The structural analysis started with the deconstruction of the narrative though an interrogative process resulting in the identification and coding of its key constituent elements. The process was informed by Greimas' (1987) actantial model and Polkinghorne's (1998) discussion of the constituent elements of narrative. The important narrative elements were accepted as events, actors, actions, and the spatio-temporal context. Hence the focus of the empirical analysis was the identification of the way in which these narrative elements were connected into a coherent story by a plot structure. It is important to emphasise that it is the plot structure of a narrative that assigns the significance to the selected events, actors and the actions (Polkinghorne, 1998). The narratives crafted by such a process constitute temporal and socially constructed artefacts. Hence they provide important contextual knowledge which may not otherwise be readily available.

The second part of the empirical analysis sought to identify the common themes around which the sectoral level narrative was constructed. These were identified through a process of multiple readings with the aim of identifying similarities, dissimilarities, and recurrent words and themes across narrative fragments (cf. Riessman, 2008). In essence, the theme structure was created through an abductive process involving oscillation between the data and the concepts represented within the strategy literature. The competitive positioning school is especially notable for its knowledge artefacts that indicate supposed relationships between key variables (Jarzabkowski and Wilson, 2006). Other theories of competitive strategy are more conceptual in nature and have hence spawned fewer identifiable tools of analysis. It was therefore necessary to search for evidence in support of the broader-based concepts associated with the various schools of thought (see previous discussion). The concept of 'bricolage' is relevant here whereby pre-existing tools and concepts are mobilised in ways which suit the needs of the user (Jarzabkowski and Wilson, op. cit.). Hence a particular terminology can often be appropriated without any allegiance to its theoretical antecedents. 
The adopted interpretive analysis aimed to depict how the historical narratives were compiled for the envisaged strategic purposes of the sector. It is argued that the implied distinctions between actors, events and actions are shaped by the intentions of the narrators rather than an historical objective reality. Hence, the sectoral narrative of Turkish contractors is seen to be a crafted artefact resulting from a negotiation which took place between two primary narrators: the TCA directorate and the History Foundation. The analysis focused in particular on the way the intended strategic purpose played an important role in constructing an epic plot structure based on a selection of narrative fragments. The essential point is that the plotline of the constructed narrative constitutes a negotiated memory of the past together with a set of strategy resources for shaping the future of Turkish international contracting.

\section{FINDINGS AND DISCUSSION}

The generic TCA narrative notably depicts the 40-year history of Turkish international contractors as an adventure. The subject of the story emerges as either the companies or the senior managers. Both are invariably described as heroes when they are associated with successful outcomes regarding the expansion of Turkish contractors in international markets. But the same actors can easily turn to villains when their actions are retrospectively associated with failure. The object (the end goal) is described as the creation of new markets with a view to ensuring continued success. This is seen to be achieved by overcoming the barriers presented by particular geographies together with the challenges of operating in conflict zones. The generic narrative is relentlessly positive in emphasising the achievements of Turkish contractors, but the narrative fragments drawn from senior managers represent a more heterogeneous set of voices which accommodates successes and failures. The emphasised themes in the narrative fragments frequently point towards the helpers that 
should be strengthened and the opponents that need to be overcome. These narrative fragments clearly draw selectively from the past with a view to emphasising what might be important in the future. This reflects the use of historical stories to legitimise some practices while discrediting others (cf. Foster et al., 2017). The details of the narrative also provide insights into the actors, actions, and events which are deemed to be important. This again is representative of the choices being made in terms of the elements which considered to be deserving of emphasis, and hence need to be linked into the plot structure. The sub-titles below reflect the emergent findings from the thematic analysis. The discussion also draws from the results of the structural analysis in terms of the way in which events, actors, actions and spatio-temporal context were linked together to form a coherent overall plot structure.

\section{The 'initiators' of internationalization}

The analysis of the TCA narrative demonstrates that the starting point for the internationalization of Turkish contracting is associated with two primary themes. The first relates to the capabilities of the firm, with a particular emphasis on the entrepreneurship of the owner-managers. The narrative presents the owner-managers' vision as the catalyst for internationalization. But there is also a recognition that companies are dependent upon developing the necessary level of technical, managerial and financial maturity. The narrative at various places alludes to the importance of competences, capabilities and know-how thereby resonating with the discourse of capability theory.

However, the most important capability is seen to be that of entrepreneurship - to take risks in overcoming the obstacles presented by challenging markets. Yet the co-founder of one company describes how they had little choice other than to explore overseas markets: 
After the port project in [Turkey], we did not find a project in our size and ability in the domestic market, hence we had no option other than to explore overseas markets (quotation from biography of Fevzi Akkaya cited in Tayanç, 2011:19)

Notwithstanding the above, the TCA narrative repeatedly depicts contracting companies' founding owner-managers as heroes who created opportunities out of nothing in the deserts of the MENA. They are consistently presented as the key protagonists who repeatedly perform heroically to find temporary solutions to complex problems in adverse conditions:

He won the agreement that he did with the [Client] he dug both tunnels and got the project done before the Haj season. He made a rough spray alum and opened the tunnels for Haj [temporally]..and with this job, our firm had settled in Saudi Arabia... (quotation from biography of Fevzi Akkaya cited in Tayanç, 2011:54)

The above quotation emphasizes the company manager's heroic action to support the annual Muslim pilgrimage to Mecca. The subsequent part of the narrative fragment celebrates how an innovative temporary solution enabled the company to become embedded in the Saudi market. Consideration also needs to be given to the way in which owner-managers are empowered to make such decisions in response to emergent problems. In the context of Western plcs such autonomy might be perceived as an inappropriate lack of governance. More importantly, presenting a heroic character who is empowered to make decisions generates an important point of reference for subsequent generations of managers. And it certainly provides for a more exciting narrative than simply emphasising the need to develop the appropriate capabilities (although both are seen to be important).

The TCA narrative is further notable for bolstering the credibility of the depicted epic storyline by including quotations drawn from the foreign media:

The works and successful performance of Turkish contractors in Libya were covered in the foreign media, which described how 'Turkey is getting hold of the Libyan 
market with a decisive breakthrough, and signs new works with incomprehensible success'... (quotation from magazine article by Büyüteç cited in Tayanç, 2011:83).

The phrase 'incomprehensible success' serves to reinforce the acclaimed heroic characteristics of Turkish contractors. The narrative also emphasises the importance of diversification by investing in business lines beyond contracting. Indeed, the concept of an investor-contractor is repeatedly positioned as a helper throughout the TCA narrative, thereby again shaping the future expectations of member companies. Many Turkish contractors have indeed since chosen to invest in a range of diverse subsidiary markets, not least real estate, energy and manufacturing. Since the early 2000's others have chosen to develop their capabilities as an operator-contractor in BOT-type projects. Specialization in airport projects, power plants and the heath sector, both in the domestic and international markets, are key examples. There are clear connotations here of competitive-positioning theory.

The second theme relating to the initial steps of internationalization relates to the (recurring) economic and political crises in Turkey and the consequent stagnation in the domestic market. These are variously described as 'push factors', whereby the government emerges as the initiator of the heroes' expansion into the international arena. In the words of one quoted manager:

As you know, there has been a decrease in domestic investment in Turkey lately, as a result, contractors are speeding up international contracting as previously happened in the 1980s, 1970s... (Interview with Bülent Erdoğan cited in Tayanç, 2011: 237)

It is notable that the narrative does not position such 'push factors' as having shaped the trajectory of Turkish contractors in isolation; emphasis is given to the way in which several factors interacted. For examples, the high construction demand in oil-rich countries such as 
Libya in the 1970s, and across the MENA region more broadly in the 1980s, were interpreted as helper events. The subsequent decline in construction demand during the second half of the 1980s due to the reduced oil price is thereafter positioned as an opponent. The plotline is that high oil prices initially helped Turkish contractors, but the ensuing reduction in the global oil price was a problem which had to be overcome. The storyline progresses by emphasising the dissolution of the Soviet Union as a pivotal moment for Turkish contractors, not least because of the subsequent opportunities within the newly emergent CIS countries where demand had previously been suppressed. Hence the emergent opportunities within CIS are positioned as the new helper in creating markets for the Turkish international contractors who were at the time struggling throughout the MENA region:

In fact, the opening of these new markets in the former Soviet Union took place just in time considering [...] the decreasing job opportunities in Libya in the late 1980s, and the market shrinkage in the Middle East market after the first Gulf Crisis. (Tayanç 2011:122).

Involvement in international contracting is also interpreted as a consequence of the liberalization of Turkey's economy in the 1980s. Government initiated business delegations, changes in overseas business legislation and the convertibility of the Turkish currency are suggested as having been of particular importance. The narrative hence points towards government policies which have been helpful in the past, with an implied suggestion that the sector is likely to continue to depend upon supportive government policies in the future. It is notable that the narrative falls short of Öz's (2001) rather harsher criticism of the lack of support from the Turkish government.

The TCA narrative is also strong in attributing agency to a few key protagonists who are seen to have had a big impact on the internationalization of Turkish contractors. First, Turkish contracting firms were exempted from the preconditions required to bid for new projects in 
Libya by the actions of prominent key actors. This is attributed to be a consequence of Libyan government officials being educated in Turkey in the 1950s with direct financial assistance from Turkish government scholarships. Colonel Gaddafi, President of Libya (1969-2011), is also positioned as a helper due to his tendency to favour Turkish contractors over Western firms. The third key actor to be given prominence is the former Prime Minister and President of Turkey, Turgut Ozal. His economic restructuring agenda of the 1980s is described as one of the key helpers in enabling the expansion of Turkish international contracting. The story of the first tentative steps towards internationalization also places great emphasis on the importance of operating as a main contractor rather than accepting the more limited role of sub-contractor. Interestingly, the status of being labelled an international contractor' is denied to those firms working only as sub-contractors. Hence, the narrative creates a strong future expectation that firms operating as sub-contractors should aim to progress to main contracting. There are again nuances here of Porter's notion of competitive positioning within the value chain.

\section{We love to work in high-risk markets}

Several narrative fragments emphasise the adventurous and risk-seeking nature of Turkish people. A risk-taking attitude is described as a key characteristic that differentiates Turkish contractors from their competitors. A more cynical reading of the narrative might suggest that Turkish contractors had little option other than to operate in risky markets given that other markets were already dominated by Western companies. However, such an interpretation would not fit the brief of celebrating the success of Turkish contractors, and nor would it contribute to the self-identity of the firms' owner-managers. Hence assigning a heroic stance is much more 'on message' than describing such markets as the choice of last resort. But the narrative is also careful to position risky markets as providing an opportunity to move into 
emerging markets rather than being an end in themselves. The two quotations below provide examples of the various nuances:

I have no expectation that somebody will deliver a project to me in Champs Elysees, I know that I need to go tough countries (quotation from newspaper article on Şarık Tara cited in Tayanç, 2011:139).

I don't expect that Western companies will pay attention to the Afghan market, because the conditions are very difficult...As it will be a door to open other global markets, it is very important for Turkish firms (Interview with İbrahim Çeçen cited in Tayanç 2011:246).

Hence the narrative seems to suggest that developing capabilities by working in risky markets creates the opportunities to operate successfully in less-hostile environments. There is a clear path dependency argument relating to the need for firms to develop track records in targeted locations. If a firm can develop a reputation for delivering on time in hostile environments, this would undoubtedly enable them to be more competitive in positioning themselves in developing markets elsewhere. The narrative would seem to be reinforcing this reputation as a means of encouraging similar entrepreneurial behavioural by future generations. However, it is important to note that Turkish contractors are seemingly willing to accept lower risk premiums than their European rivals. In the words of one manager:

We are willing to accept lower rates of profit, which is another factor, an important factor. When Europeans make the costing they add $20 \%$ risk premium, if the county is very risky they add 35\%, but we add 5, 8 or $10 \%$... (Interview with Emre Aykar cited in Tayanç 2011:298)

A recurring theme of the narrative is that risk taking is an intrinsic quality of Turkish contractors: 
We have to be successful... When you say 'we have to be successful', it means you are ready to act aggressively and give any kind of self-sacrifice if necessary. We are eager to get a job and to do the job. This is really important...Turkish people are hungry to succeed... we yearn success both for us and for our country. (Interview with Eyüp Yiğit cited in Tayanç 2011:303)

The above quotation highlights the way in which risk-taking is connected to the deeper cultural norms which support the self-identity of the Turkish people. Similar examples occur throughout the TCA narrative, especially in terms of social behaviours such as 'make it up as you go along'. There would seem therefore to be clear rejection of the idea that 'planning' can be separated from 'doing'. Indeed, the phrase 'make it up as you go along' would seem to resonate with the principles of strategy-as-practice. The TCA narrative also legitimatizes international contracting as a key sector that contributes to the Turkish economy, not only in terms of foreign earnings, but also in terms of creating employment. This again would seem to be a message aimed at the Turkish government.

\section{The requirement for financial and consulting capabilities}

Two further recurring themes emerge as the limited financial capabilities of Turkish contractors and the absence of any consultancy expertise. Both of these are presented in the narrative as significant opponents to be overcome if the heroes are to be successful in international markets. The discussion tends to be conducted in the language of 'capabilities' yet the longstanding failure to develop such capabilities is not allowed to distract from the epic success story of Turkish international contracting. Reference is made to the recurrent problems which Turkish firms face in gaining 'letters of guarantee' to be included in tender submissions. Other key problems highlighted are the high rates of interest in return for access 
to finance and the lack of a well-developed insurance system. The narrative therefore tends to position the banking sector in Turkey in the role of opponent. The overriding message is that Turkish contractors are financially disadvantaged in comparison to their Western counterparts. This is especially true when tendering for mega projects which are routinely reliant on project credits and financial guarantees provided by government and/or the Exim banks. In the words of one quoted manager:

The biggest problem for Turkish firms is the letters of guarantee... If you undertake a 700 billion US \$ project, you need a security deposit of at least $25 \%$ to $30 \%$ of the total value... It is impossible to get these from Turkish banks... (Interview with Oktay Yavuz cited in Tayanç 2011:235).

Several of the narrative fragments refer to critical actions taken by the contractors to overcome such financial difficulties. These actions can easily be labelled as 'enacted strategies' that might guide future generations. One is the strategy of establishing local subsidiaries in targeted markets. They then seek to access finance through local banks in the name of their local subsidiaries. The other action outlined in the narrative is to work in partnership with Western contractors. This enables Turkish contractors to become eligible for Western finance on the basis of being a joint venture (JV) partner. Although rarely mentioned, a third action flagged in the narrative is to secure guarantee of letters from Turkish banks on the basis of government lobbying. It is notable that the positioning of the Turkish government varies in accordance with the argument being made at the time. Government is on occasion positioned as a helper, but is also frequently positioned in the role of opponent in respect of its occasional perceived failure to provide the required financial guarantees. 
The second theme that is positioned as an opponent is the inability of Turkish consultancy firms to compete internationally. The TCA narrative emphasises that the formalised tendering procedures as advocated by Western consultancy firms pose a big obstacle to Turkish contractors. Such procedures are seen inevitably to promote Western standards and products. The point is emphatically reinforced by a quotation from the Turkish Ministry of State:

It is extremely important that Turkish consulting firms should take, win, and prepare the projects prior to Turkish contractors delivering them. We give serious support to this...For example, we will contribute by allocating 30 million US \$ to support the costs for opening an office overseas, and by giving government support to the contracts that they sign. I say to our consulting firms 'Bring me such ideal and good projects that Turkish contracting firms can undertake using Turkish construction materials and you can take the cost of project from me... (Interview with Zafer Çağlayan cited in Tayanç 2011:332)

The above quotation supports the broader strategic narrative that the development of Turkish consulting services should be a key agenda, not only for the TCA, and also for the Turkish government. The emphasis on the need for a Turkish consulting sector notably emerges as a more recent theme. In contrast, the lack of financial capability is interpreted as having been an on-going problem from the outset.

\section{Mobilization of the Networks}

The narrative theme relating to the importance of networks emerges in a number of different forms. One is the emphasis given to the historical and cultural connections between Turkey and its targeted markets. The TCA narrative suggests that the preferred markets of Turkish contractors lie along the traditional trading the routes of the Ottoman Empire. The narrative is especially strong in emphasising that Turkey's cultural connectivity gave it a distinct advantage in accessing MENA markets during the first two decades of international 
contracting. These markets are seen to be more accessible to Turkish contractors because they have similar religious/cultural values. The inference is that for whatever reason such clients often feel uncomfortable to letting work to Western contractors. The narrative thereafter makes much of the way that the experience gained in these markets was subsequently mobilized in Russia, and across the former southern Soviet republics of Central Asia. The key point is emphasised in the concluding chapter of the book:

In [the internationalization] process, Turkish contractors benefited from ...the common historical and cultural background with Middle East, North Africa and Turkic Republics... it is obviously because of the historical and cultural connections that came from living together in the vast geography of the Ottoman Empire in addition to the blood ties. When such markets are compared with those of the West, Turkish contractors benefit from being in markets that don't have 'the legal and administrative infrastructure established in Western countries, and the former colonies that they continue to dominate. (Tayanç 2011:330).

As seen in above quotation, the narrative clearly highlights the historical and cultural connections as a helper to create new markets. Russia however constitutes a markedly different case. Turkey and Russia have a long-established trade relationship which seemingly survives periods of stained diplomatic relations. The strong emphasis on Russia is perhaps primarily influenced by its perceived strategic importance in the future.

Government lobbying also emerges as a key theme that is emphasized in several narrative fragments. Turkish contractors are often invited to take part in official diplomatic visits to other countries, involving ambassadors in addition to Foreign Ministry officials. In this respect, government is firmly positioned as a helper. The storyline is reinforced by several cited narrative fragments which highlight the very close relationship between foreign diplomacy and market entry into targeted countries. In such trips, the owner-managers of the contracting companies are able to establish government level networks which are invaluable 
in paving the way for commercial opportunities. Turkey of course is not alone in dispatching government-led trade delegations, but the point of interest here is that they are such an explicit theme within the strategic narrative. The trade agreements signed with Libya in the 1970s and the USSR in the 1980s are presented to be particularly important to the subsequent path trajectory of Turkish contracting. This is undoubtedly a retrospective interpretation. The broader message is presumably aimed at the Turkish government with a view to ensuring similar support in the future.

Following on from the above, there are several narrative fragments which argue that lobbying by government is a common strategic action for all countries. Within the TCA narrative, France is the most frequently cited example. Most notably, winning a tender for a megaproject is routinely represented as a victory for one country over another. In such narrative fragments the subject of the narrative shifts from the role played by company leaders to that of the Turkish government whereby presidents and diplomats are underlined as key helpers. From a quotation of a Turkish newspaper article in 2005:

Foreign Minister, [Abdullah] Gul won his second victory over French President, Chirac in international tenders... (Newspaper article cited in Tayanç 2011:238)

Lastly, it is pertinent to highlight the way in which the narrative fragments allocate roles to personal friends in introducing owner-managers to new markets. The mobilisation of individual contacts is repeatedly cited as one of the key actions that shaped the internationalization of Turkish contractors. Personal contacts are of course important for business development everywhere, but they are especially important within Middle Eastern cultures. The following quotation illustrates the point:

Following the dissolution of the Soviet Union in 1991, we were faced with the new republics of the Commonwealth of Independent States. There was a 
Yugoslavian with whom we were doing business at that time. He ... convinced us of the high construction potential in Kazakhstan and asked whether we would be interested. We accepted his invitation. (Magazine article from 1999 quoting Haluk Kaya cited in Tayanç 2011:173).

In a similar vein, many narrative fragments attach significant importance to the networks originally created by working as a sub-contractor to Western contractors in Turkey. For many companies, their initial overseas contracts were seemingly acquired through working with Western firms as subcontractors on Turkish domestic projects during the 1940s/50s. It is notable how little emphasis is given to the importance of building networks within the construction-related strategy literature, with the notable exception of Kao et al. (2009).

\section{Avoiding 'internal' competition}

The narrative depicts the failure of Turkish firms to cooperate with each other as a key opponent which inhibits competitiveness of Turkish contracting. More pointedly, Turkish contractors are themselves positioned as opponents as a consequence of their alleged tendency to compete with each other on cost. This is repeatedly raised as a problem, starting with Libya in the 1980s right through to the Afghan market of the 2000s. The cited interview with a former government official is especially telling:

It happened everywhere, in Libya, in the Middle East, in Central Asia, in Afghanistan. Competition among [Turkish contractors] was everywhere. In a sense, whenever a few companies earned good money and started to get jobs; everyone started to enter the same market. This increased competition... by lowering prices. And then some of the companies working at very low prices failed to finish jobs. Some projects were left unfinished, and problems arose in some countries, or they led to a number of negative consequences (Interview with Hikmet Çetin cited in Tayanç 2011:332).

The TCA narrative specifically highlights the short-term JVs set up to bid for projects in the 
Soviet Union in late 1980s and thereafter in the Russian Federation of the early 1990s. These are seen to be important in paving the way for the initial foothold of Turkish contractors in post-Soviet CIS states. The use of phrases such as 'band together to bid' (p.122) seems to give a clear message about the need to avoid needless competition between Turkish contractors. The names of successful JVs are listed to emphasize their helper role to win the tenders in overseas. However, the temporality of such cooperative initiatives is highlighted as an opponent that should be overcome. The following quotation reflects the call for more cooperation in the future:

This is first time that we bring our powers together without any foreign company... We prevent unfair competition... We have a bad experience in Libya that firms competed on lowest costs. This is a good start...(Newspaper article quoting Ümit Özdemir cited in Tayanç 2011:281).

Although the idea of 'combining powers' emerges as a key theme in the TCA narrative, the narrative fragments from different sources depict 'competition on low cost' as an on-going problem of Turkish contractors. The narrative notably highlights the TCA's preference for consolidation as a means of avoiding cost competition among members:

We can see that one or more Turkish companies compete with each other in almost all countries and project types. This of course is another problem of us in general... This is not easy to handle, but what only could be done in here: cooperation. I think, the best thing, if one or two companies come together and establish a partnership on a project basis and establish a business partnership and bid together on a project. Otherwise we start breaking down each other by lowering the prices, reducing the margins (Interview with Emin Sazak cited in Tayanc 2011:332).

The message here is very clear, and very much directed at the future. Simply stated, it is not deemed sensible for Turkish contractors to be competing among themselves. Such an 
argument of course is indicative of an underlying mercantilist perspective.

\section{Building brand recognition}

The TCA narrative emphasizes the importance of creating a collective brand image for Turkish contracting. Although there are subtle nuances across different narrative fragments, the narrative as a whole seeks to build brand recognition primarily on the basis of early project completion and an adversity to contractual litigation on the part of Turkish firms. Emphasis is also given to their commitment to quality, which is frequently used as a characteristic to distinguish Turkish firms from their Chinese state-owned competitors. In the words of one company owner:

...the Chinese were working in front of us; and the Indians were working behind us. Everyone saw that we did the most successful work; we did it very well before than the expected time...So we are recognized in India... We did few more works with this firm [the client], and we continued to work (Interview with Nihat Özdemir cited in Tayanç 2011:245).

Especially important is the acclaimed reputation of Turkish firms for early completion, which seems to have been adopted as a motto by some companies. Several narrative fragments emphasize the number of days won by early completion. It is particularly emphasised in the context of build-operate-transfer (BOT) projects. The claim that Turkish firms have a unique capability in consistently achieving early completion would seem to draw from the narrative of capability-building theory. The narrative specifically links the reputation of Turkish firms to the flexibility and hardworking character of Turkish people. The implication is that such capabilities cannot easily be replicated by others. The narrative is undoubtedly selective in its supporting evidence; but the argument is not really about past performance, it is about the future. The narrative serves to build a collective commitment to early completion such that it becomes an issue of national pride. It is easy in this respect to understand how a strong and 
consistent narrative can indeed be constitutive of the desired reality that Turkish contractors deliver on time. One especially vivid narrative fragment presents an example from Russia in the early 1990s:

Yeltsin bombed the Parliament building...then ordered the renovation of the [Russian] White House...They wanted it done in a short time...two and a half Ithree months...As they saw our work in Gazprom, they asked us to do the work... it took great courage to undertake such a project in winter time... We accepted and finished before the end of the year... The parliament gave us an expression of appreciation... (Interview with Erol Üçer cited in Tayanç 2011:157).

The firm undoubtedly benefited from the resultant publicity from such a prestigious renovation, but in terms of a strategic narrative it is the internalisation of the message which is arguably of primary importance.

The TCA narrative also emphasises a supposed aversion to contractual litigation on the part of Turkish contractors. This is purported to be a key characteristic which differentiates Turkish firms from their competitors:

One of the most important points of Turkish contractors' reputation in the world today is that they do not engage in wrong behaviour that would cause a dispute with any country. Being the side that gives concessions all the time and moving in the direction of their will has brought great advantages. You do not win anything from the conflict... (Interview with Bedri Sever cited in Tayanç 2011:244).

Another important contribution to brand recognition are the numerous actions taken to ensure that Turkish contractors are included in the 'approved contractors' lists of the leading international institutions. The inclusion on such lists is held to be especially important in overcoming Turkish contractors' traditional lack of financial capabilities. In the words of a TCA representative: 
The firms that have close relationships with the international institutions will have more chance in the long term. In long term projects, the companies who can enter the qualification list of the institutions such as World Bank and Asian Development Bank can get a share from the [Afghan] market (Interview with Nihat Özdemir cited in Tayanç 2011:246).

The inclusion on this list is seen to be especially important to ensure that Turkish contractors are well placed to participate in mega-projects. Similarly, setting up long-term JVs with USbased contractors or asserting the identity of Turkish firm as 'NATO contractors' are depicted as important means of breaking into the European and African markets. The narrative is at pains to emphasise that building the brand of Turkish contractors has been a long-term project. The inference is that the next generation of owner-managers carries the responsibility for maintaining this brand into the future.

\section{CONCLUSION}

The content of the Geography of Contractors ostensively provides a quasi-historical commentary of how Turkish contracting firms have become competitive in international markets. The generic narrative highlights the achievements of individual firms in establishing themselves across a geographical spread of diverse and often very challenging markets. The actors and actions are portrayed against a background of selected geo-political events and are positioned chronologically in a supposedly realist timeline. However, the text also contains 54 'narrative fragments' derived from senior politicians, industry representatives and senior managers from within the TCA's membership firms. There is also an occasional quotation from external media sources where these are perceived to add credibility. The broad approach resonates with the canons of the process school which advocates that strategy can only be understood as a process which unfolds over time (cf. Pettigrew, 1997). However, in contrast to the realist use of the past inherent within Pettigrew's work, the narrative fragments give 
vent to a diversity of individualised perspectives with little attempt to verify the claims being made. It is clear that each narrative fragment offers a selective interpretation of past events, and it seems reasonable to suggest that the interpretations are offered as a means of linking the past with the future (cf. Czarniawska, 2004). Hence the narrative fragments should be read not only in terms of what they say about the past, but also in terms of what they say about the future.

Insights can be gleaned not only from the narrative fragments themselves, but also from the very fact that they were chosen for inclusion in the generic narrative. Here again it is contended that the TCA narrative draws from the past selectively to provide a meaningful plot structure within which to present the selected stories (cf. Foster et al., 2017). Although not described explicitly, the intended audience for the narrative seems to be Turkish contractors who work (or intend to work) in international markets. The narrative also seeks to legitimize TCA membership as a badge of endorsement in the eyes of the Turkish Government and in the perception of potential clients in international markets. This in part is about building brand recognition, but it is also about the social construction of a future reality. The narrative builds a strong expectation that Turkish contractors will deliver on time, avoid adversarial relationships with their clients and compete on the basis of quality. The stories which are included to support past claims may well be selective, but the expectations for the future are nevertheless very clear. It could be argued that Turkish contractors are saddled with the expectation of living up to the heroic deeds of the previous generation; a more positive interpretation is that they are empowered by the way such expectations mobilise national pride in the cause of commercial success. 
The narrative as a whole assigns heroic roles to key individuals in forging the success of Turkish contractors. More often than not, the heroes are the owner-managers of previous generations. The epic plot structure can further be seen to cast others in the role of villains if they are retrospectively associated with failure (cf. Barry and Elmes, 1997). Events and actions are also variously cast in the 'roles' of helpers or opponents. As such they are seen to have played an important part in the stories of how the implied heroes undertook their epic journeys to the desired end goal. The allocation of agency is of course highly selective and the choices are consistently made for the purposes of creating a particular plot structure. This again is part of an interpretive process. It is further important to recognise that some 'events' are deliberately emphasised, and others correspondingly de-emphasised. It is notable the events are described as 'things which just happen', while the actions emerge as the things which are actively enacted by the heroes (or villains).

If narratives are to be influential they must of course be credible to the intended audiences. In this respect, prima facie factual accuracy is important. The engagement of the History Foundation of Turkey in itself serves to strengthen the credibility of the narrative. The narrative of course is strengthened if it is supported by facts, but it is not the facts themselves which tell the story. It is the plot structure which is constructed around conveniently selected facts which tells the story, and it is the persuasiveness of the story which will dictate how effective it is in shaping the future.

The TCA narrative can hence be seen to comprise a skilfully designed strategy product on the sectoral level. It is produced not only to create a shared memory and point of reference for future generations, but also to legitimize some practices and discredit others. The narrative gains credibility by compiling a heterogeneous and multi-voiced conversation amongst the heroes of Turkish contracting. It is notable that the narrative fragments reflect an inherent 
dynamism and temporality in the use of historical narratives for strategic purposes (cf. Foster et al., 2017). The helpers described in one narrative fragment easily turn to opponents in other fragments. There is also often a seamless transition through which heroes become recast in the role of villains. The analysis of narrative fragments further illustrates the temporal interpretations and connections made between the actors, the actions that they take, and the events that are initiated by external parties (cf. Fenton and Langley, 2011). The connections are presented from the perspective of the narrators for the purposes of making a particular argument. Such connections provide the basis for understanding how different actions are taken in different situations, and how they may subsequently be interpreted as strategy. More importantly, the narrative fragments reflect the interaction of multiple realities and signify the complexity of, and diversity across, individual accounts of strategy making (cf. Brown and Thompson, 2013). The findings suggest that strategic actions can only ever be identified in retrospect, and even then such arguments are always made with an eye on the future. This conclusion offers a strong contrary argument to the dominant thinking within the construction-related literature on strategy, although it certainly chimes with aspects of strategy-as-practice (cf. Whittington, 2006). Indeed, it could be argued that the Geography of Contracting represents strategy-as-practice frozen at a point in time.

The significance of the reported research is of course by no means limited to Turkish international contracting. The use of historical narratives as a source of strategic resources is undoubtedly equally applicable to other major players in international contracting. Indeed, it could be argued that the absence of any effort to create and sustain a strong sectoral-level narrative potentially acts as a strategic disadvantage, not least because it deprives individual firms of strategic resources from which they can draw. Other construction-related researchers have previously championed the cause of narrative analysis. Nevertheless, the research 
described in this paper is held to be original in its theoretical underpinnings, especially in terms of the focus on historical narratives as sources of strategic resources. The methodology further provides an essential corrective to the recurring over-reliance on questionnaire surveys and semi-structured interviews within the construction-related research community. Of particular importance is the way in which the described research legitimises alternative sources of empirical data, not least those which might be found in archival sources and the grey literature.

\section{REFERENCES}

Adorisio, A. L. M. (2014) Organizational remembering as narrative: 'Storying' the past in banking. Organization, 21(4), 463-476.

Ansoff, H. I. (1965) Corporate Strategy, Penguin, Harmondsworth.

Barney, J. (1991) Firm resources and sustained competitive advantage. Journal of Management, 17(1), 99-120.

Barry D. and Elmes, M. (1997) Strategy retold: Toward a narrative view of strategic discourse. Academy of Management Review, 22(2), 429-452.

Brown, A. and Thompson, E. (2013) A narrative approach to strategy as practice. Business History, 55(7), 1143-1167.

Brunninge, O. (2009) Using history in organizations: How managers make purposeful reference to history in strategy processes. Journal of Organizational Change Management, 22(1), 8-26.

Chandler, A. D. (1962) Strategy and Structure. MIT Press, Cambridge.

Crosthwaite, D. (2000) The global construction market: a cross sectional analysis. Construction Management and Economics, 18(5), 619-627.

Czarniawska, B. (2004) Narratives in Social Science Research. Sage Publications, London.

De Haan, J., Voordijk, H. and Joosten, G. J. (2002) Market strategies and core capabilities in the building industry. Construction Management and Economics, 20(2), 109-18.

De La Ville, V. and Mounoud, E. (2015) A narrative approach to strategy as practice: strategy making from texts and narratives, in: Golsorkhi, D., Rouleau, L., Seidl, D. and Vaara, E. (eds.) Cambridge Handbook of Strategy as Practice, Cambridge University Press, Cambridge, pp. 247-264. 
Dikmen, I. and Birgönül, M. T. (2003) Strategic perspective of Turkish construction companies. Journal of Management and Engineering, 19(1), 33-40.

Engineering News Record (ENR) (2017) The 2016 Top 250 International Contractors [online], https://www.enr.com/toplists/2016-Top-250-International-Contractors 1 [Accessed 04 January 2018]

Fenton, C. and Langley, A. (2011) Strategy as practice and the narrative turn. Organization Studies, 32(9), 1-26.

Fernie, S., Leiringer, R. and Thorpe, T. (2006) Change in construction: a critical perspective. Building Research \& Information, 34(2), 91-103.

Flanagan, R., Lu, W., Shen, L. Y. and Jewell, C. (2007) Competitiveness in construction: a critical review of research. Construction Management and Economics, 25(9), 9891000.

Foster M. W., Coraiola, D. M., Suddaby, R. Kroezen, J. and Chandler, D. (2017) The strategic use of historical narratives: a theoretical framework. Business History, 59(8), 1176-1200.

Giritli, H., Sözen, Z., Flanagan, R. and Lansley, P. (1990) International contracting: A Turkish perspective. Construction Management and Economics, 8(4), 415-430.

Grant, R.M. (1996) Toward a knowledge-based theory of the firm. Strategic Management Journal, 17, 109-122.

Green, S. D., Harty, C. F., Elmualim, A. A., Larsen, G. D. and Kao, C. C. (2008a) On the discourse of construction competitiveness. Building Research \& Information, 36(5), 426-35.

Green, S. D., Larsen, G. D. and Kao, C. C. (2008b) Competitive strategy revisited: contested concepts and dynamic capabilities. Construction Management and Economics, 26(1), $63-78$

Greimas, A. J. (1987) On Meaning: Selected Writings in Semiotics Theory. University of Minnesota Print, Minneapolis.

Holstein, J. A. and Gubrium, J. F. (2011) Varieties of Narrative Analysis. Sage Publications. Jarzabkowski, P. (2005) Strategy as Practice: An Activity-Based Approach. Sage Publications, London.

Jarzabkowski, P. and Wilson, D. C. (2006) Actionable strategy knowledge a practice perspective. European Management Journal, 24(5), 348-367. 
Jarzabkowski, P. and Spee, A. P. (2009) Strategy as practice: A review and future directions for the field. International Journal of Management Reviews, 11(1), 69-95.

Kao, C. C., Green, S. D. and Larsen, G. D. (2009) Emergent discourses of construction competitiveness: localized learning and embeddedness. Construction Management and Economics, 27(10), 1005-1017.

Korkmaz, S. and Messner, J. I. (2008) Competitive positioning and continuity of construction firms in international markets. Journal of Management in Engineering, 24(4) 207216.

Langford, D. and Male, S. (2001) Strategic Management in Construction. Blackwell Science, Oxford.

Lee, S. H., Jeon, R. K., Kim, J. H. and Kim, J. J. (2011) Strategies for developing countries to expand their shares in the global construction market: phase-based SWOT and AAA analyses of Korea. Journal of Construction Engineering and Management, 137(6), 460-470.

Löwstedt, M. and Räisänen, C. (2012) 'Playing back-spin balls': Narrating organizational change in construction. Construction Management and Economics, 30(9), 795-806.

Lu, W. (2014) Reliability of Engineering News-Record international construction data. Construction Management and Economics, 32(10), 968-982.

Mawhinney, M. (2001) International Construction. Blackwell Science, Oxford.

Mintzberg, H. (1987) Crafting strategy. Harvard Business Review, July-Aug, 65-75.

Mintzberg, H. (1990) The design school: reconsidering the basic premises of strategic management. Strategic Management Journal, 11(3), 171-195,

Ministry of Economy (2018) Yurtdış1 Müteahhitlik Sektör Değerlendirme Raporu [online] https://www.ekonomi.gov.tr/portal/faces/home/hizmetTicareti/ydmh/ SektorHakkinda [04 January 2018]

Nelson, R. R. and Winter, S. G. (1982) An Evolutionary Theory of Economic Change. Harvard University Press, Cambridge, MA.

Ofori, G. (2003) Frameworks for analysing international construction. Construction Management and Economics, 21(4) 379-391.

Öz, Ö. (2001) Sources of competitive advantage of Turkish construction companies in international markets. Construction Management and Economics, 19(2), 135-144.

Özorhon, B. (2012) Türkiye'de Inş̧aat Sektörü ve Dünyadaki Yeri. İstanbul Ticaret Odasi Yayınları, Istanbul. 
Pettigrew, A. M. (1997) What is processual analysis? Scandinavian Journal of Management, 13(4), 337-48.

Polkinghorne, D. E. (1998) Narrative knowing and human sciences. State University of New York, Albany, NY.

Porter, M. E. (1980) Competitive strategy: Techniques for analysing industries and competitors, Free Press, New York, NY.

Porter, M. E. (1990) The Competitive Advantage of Nations, Free Press, New York, NY.

Prahalad, C. K. and Hamel, G. (1990) The core competence of the organization. Harvard Business Review, 68(3), 79-91.

Raftery, J., Pasadilla, B., Chiang, Y. H., Hui, E. C. M. and Tang, B. (1998) Globalization and construction industry development: implications of recent developments in the construction sector in Asia. Construction Management and Economics, 16(6), 729737.

Riessman, C. K. (2008) Narrative Methods for the Human Sciences. Thousand Oak: Sage Publications.

Rowlinson, M., Casey, A., Hansen, P. H. and Mills, A. J. (2014) Narratives and memory in organizations. Organization, 21(4), 441-446.

Saldana, J. (2015) The Coding Manual for Qualitative Researchers, London: Sage.

Suddaby, R., Foster, W. M. and Quinn-Trank, C. (2010) Rhetorical history as a source of competitive advantage, in Baum, J. and Lampel, J. (eds.) Advances in Strategic Management: The Globalization of Strategy Research, Emerald Group Publishing, Bingley, pp. 147-173.

Tayanç, T. (2011) İnşaatçıların Coğrafyası: Türk Inşaat Sektörünün Yurtdışı Müteahhitlik Hizmetleri Serüveni. Ankara: Tarih Vakf .

Turkish Contractors' Association (TCA) (2017) Türk yurtdışı müteahhitlik hizmetleri [online] http://www.tmb.org.tr/tr/yayinlar/arastirma-ve-yayinlar/turk-yurtdisi-muteahhitlikhizmetleri/12 [accessed 04 January 2018]

Teece, D. J., Pisano, G. and Shuen, A. (1997) Dynamic capabilities and strategic management. Strategic Management Journal, 18(7), 509-533.

Tsoukas, H. (1994) Refining common sense: Types of knowledge in management studies. Journal of Management Studies, 31(6), 761-780. 
Vaara, E., Sonenshein, S. and Boje, D. (2016) Narratives as sources of stability and change in organizations: Approaches and directions for future research. The Academy of Management Annals, 10(1), 495-560.

Whittington, R. (1996) Strategy as practice. Long Range Planning, 29(5), 731-735.

Whittington, R. (2006) Completing the practice turn in strategy research. Organization Studies, 27, 613-634.

Zhao, Z., Shen, L.Y. and Zuo, J. (2009) Performance and strategy of Chinese contractors in the international market. Journal of Construction Engineering and Management, 135(2), 108-118.

Zollo, M. and Winter, S. G. (2002) Deliberate learning and the evolution of dynamic capabilities. Organization Science, 13(3), 339-51.

\section{FIGURE 1}

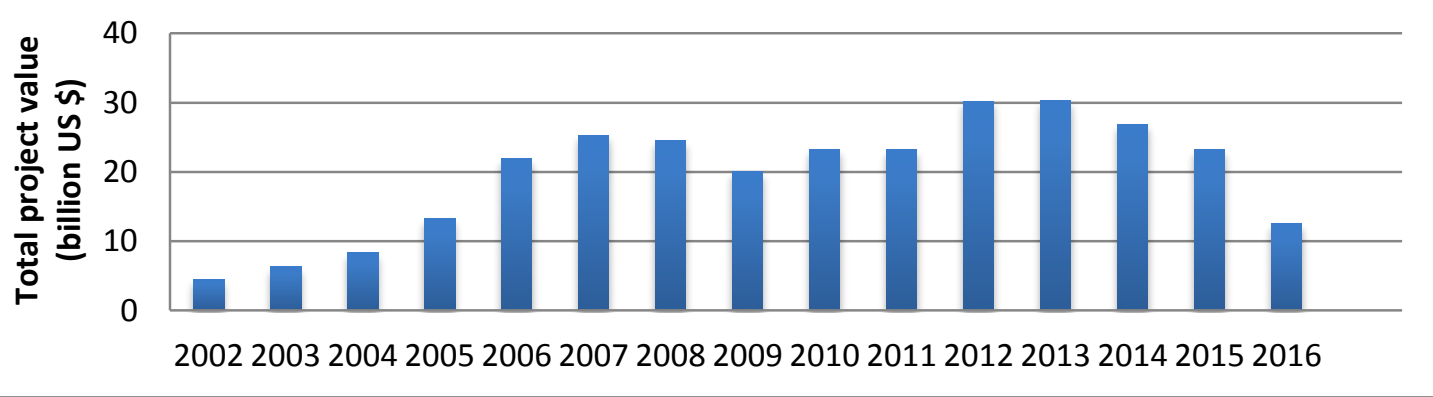

Figure 1: Annual total project values of Turkish international contractors (2002-2016) (adapted from TCA, 2017) 